\title{
Study on the Development and Marketing of Mobile TV Programs
}

\author{
Yang Jing \\ Jiangxi College Of Foreign Studies
}

\begin{abstract}
Mobile TV is a star product of media integration. The state strategy of "integration of three networks" has made mobile TV convenient for people's life. While bringing users with new media experience and convenient mobile information, it has also created new market opportunities for saturated broadcasting and telecommunication business. Meanwhile, it also provides brand new marketing platforms for advertisers. In this paper, emphasis has been given to he development and marketing of mobile TV programs. First, the research background, research purpose, literature review as well as research methods are introduced. Then the advantages of mobile media are discussed with further exploration on the definition, development motivations and communicative features of mobile TV, a new medium derived from mobile media.
\end{abstract}

Keywords- mobile TV; program development; marketing

\section{INTRODUCTION}

Since the birth of we-media, it has always been human's dream to acquire information anytime and everywhere. The emergence and development mobile phones have rightly satisfied people's this desire with constant surprises. Previously, mobile phones can only be used to send messages or multimedia messages or receive mobile newspaper, and then it can be used to surf the Internet and it even be used to watch TV. With the rapid development of mobile communication technology and wide application of media digital technology, mobile phone, a small handheld media terminal, has been developed into an omnimedia by absorbing advantages from traditional media. Now it is not only a tool for communication, but also an indispensable part of people's daily life.

The mobile TV has its own unique media features for the communication contents and customers; however, it is still a new media product which needs to be constantly perfected so as to achieve recognition from customers. With the study of mobile TV, it can not only help to develop the new media industry but also enrich the communication theories under new media environment. Thus, the author thinks it is really worthwhile to study the mobile TV. In the paper, much emphasis has been given to the development and marketing of mobile TV programs, which aims to propose some constructive suggestions for the development of mobile TV industry.

\section{THE COMMUNICATIVE FEATURES OF MOBILE TV}

The new media we talk about today mainly refers to the media form based on the computer information processing technology, which are determined by technologies. The development of modern network technology and information technology has determined the physical features of new media, and it further determines the communicative features. Mobile TV belongs to such kind of new media, which embodies its charm with its unique communicative features.

\section{A. Individualized media}

Nowadays our society advocates personality and individuality, while the popularity of mobile phones right satisfies the public need to most extent. Under the traditional linear broadcasting way, audience could only passively watch particular programs in particular time, while the homogeneous traditional broadcasting mode can't meet today's users' need for media.

\section{B. Interactive media}

Human's communication has experienced interpersonal communication, mass communication and interactive communication. The previous interpersonal communication is bilateral communication with point-to-point or dialogue way. The mass communication is unilateral communication with point-to-side and monologue way. The interactive media has offered a third for for human's communication, which is electronic interactive network communication.

\section{DEVELOPMENT OF MOBILE TV PROGRAMS}

The mobile TV programs should be altered, but it is not easy to choose how to change and how much we change. Although mobile TV possesses brand new media features, its program setting still follows the traditional way besides some original programs. The customers' existing watching habits and mental sets can be greatly affected with improper innovation, which is not good to gain support and recognition from mobile users. The following contents have introduced some program innovations.

\section{A. News programs}

The news information should be fresh, concise and simple for the characteristics of mobile TV and its users. Message is suitable for the news report on mobile TV for its fast and simple language. Meanwhile, news of mobile TV can learn from news on the Internet by designing multi-layer information presenting structures, such as title level, information level, detailed report level, related reports level and so on. By this way, it can not only meet users' need for rapid browse, but also provide alternative ways for users to watch with deep understanding.

\section{B. Mobile TV series}

At present, mobile TV programs are divided into live programs and requested programs. Live broadcast is 
synchronous with traditional TV, while requested programs mainly have two forms. One is to follow the traditional way of broadcasting, that is, each episode lasts 40 to 50 minutes, which is adopted by Eastern mobile TV. The other way is to cut each traditional episode into three or four sections, which lasts about ten minutes with a subtitle for each section. Thus customers can choose what to watch by their interest. Now CCTV mobile TV programs have adopted this way.

\section{THE MARKETING STRATEGIES OF MOBILE TV}

With the constant development of enterprises and market, there have been new marketing ways consecutively such as experiencing marketing, green marketing and relationship marketing and so on. The market environment is changing all the time, so enterprises should adjust their marketing strategies timely according to their own situations and current market environment. In this paper, there are two marketing methods as follows.

\section{A. Experience marketing with user as the center}

With the increasingly stronger concepts of consumer-led and audience-centered marketing concepts, more and more enterprises are paying attention to customers' experience of products or service, which has gradually changed into the marketing concept with customer as the center. Meanwhile, consumers' consumption mode of mobile TV has also changed from the previous trying attitude to individualized experience-based consumption mode, which requires a constantly colorful TV programs to fully meet their individualized need. The promotion of mobile TV can be more easily by creating sound environment for consumers to experience the high-tech information products comfortably.

\section{VIRAL MARKETING WITH HUGE POWER}

By offering valuable products and services, we can realize marketing by mouth-to-mouth promotion. Compared to traditional marketing which relies on mass media with unilateral information communication, viral marketing makes full use of the network for its rapid, convenient and interactive information communication. By creating sound information experience, we can obtain good reputation so as to obtain explosive communication of products and services.

\section{CONCLUSION}

Mobile TV is such a new media which can create infinite possibilities and bring deep social revolution. It integrates the media features of mobiles and TV, which has become an indispensable part of people's life for its mobility, convenience and interaction. It brings brand new and multi-dimensional visual and audio experience with extreme freedom so that information can be truly assessed. For sure, current mobile TV is not perfect, and its TV programs are not colorful. Meanwhile, the development of mobile TV has also been restricted by the bandwidth. In addition, we need time to cultivate enough users. However, it needs a process for the growth and perfectness of any media. As a value-added service with the most potential in the $4 \mathrm{G}$ age, mobile TV has obtained much attention from different fields and academic world, which is under a process with constant perfection.

\section{REFERENCES}

[1] Kotler P. Marketing management : analysis, planning, implementation and control[M]// Prentice Hall International, 1997:297-320.

[2] Barich H, Kotler P. A Framework for Marketing Management[J]. Sloan Management Review, 1991, 32:94-104.

[3] Kotler, Philip, and K. L. Keller. A framework for marketing management. Pearson Education, 2016.

[4] Chonko, Lawrence B., and S. D. Hunt. "Ethics and Marketing Management: An Empirical Examination." Journal of Business Research 13.4(1985):339-359.

[5] Madsen, Tage Koed. "Successful Export Marketing Management: Some Empirical Evidence." International Marketing Review 6.4(1989).

[6 Peattie, Ken. Environmental marketing management : meeting the green challenge. Pitman, 1995.

[7] Kilgour, Mark. "Marketing Management: An Asian Perspective." Australasian Marketing Journal 14(2006).

[8] Araujo, L., A. Dubois, and L. E. Gadde. "Managing Interfaces with Suppliers." Industrial Marketing Management 28(5." International Marketing Management 17.1(1999):99.

[9] Kotler, Philip. "Marketing Management: Millenium Edition." International Edition Jan(2000).

[10] Avlonitis G J, Gounaris S P. Marketing Orientation and company Performance', in: Industrial Marketing Management 26[J]. Industrial Marketing Management, 1997, 37(3):1-2.

[11] Gummesson, E. (2002). Practical value of adequate marketing management theory. European Journal of Marketing, volume 36(3), 325-349.

[12] Mahajan, Jayashree. "The Overconfidence Effect in Marketing Management Predictions. 29." Journal of Marketing Research 1992:329-342. 